OPEN ACCESS

Edited by:

Martin Johannes Hoogduijn, Erasmus University Rotterdam,

Netherlands

Reviewed by:

Luiza Guilherme,

University of São Paulo, Brazil

Guido Moll,

Charité - Universitätsmedizin Berlin,

Germany

*Correspondence:

Ulla Impola

ulla.impola@bloodservice.fi;

Jukka Partanen

jukka.partanen@bloodservice.fi

Specialty section:

This article was submitted to Alloimmunity and Transplantation,

a section of the journal

Frontiers in Immunology

Received: 09 September 2016 Accepted: 09 November 2016

Published: 21 November 2016

Citation:

Impola U, Larjo A, Salmenniemi U,

Putkonen $M$, Itälä-Remes $M$ and Partanen J (2016) Graft Immune Cell Composition Associates with Clinical

Outcome of Allogeneic

Hematopoietic Stem Cell

Transplantation in Patients with AML.

Front. Immunol. 7:523.

doi: 10.3389/fimmu.2016.00523

\section{Graft Immune Cell Composition Associates with Clinical Outcome of Allogeneic Hematopoietic Stem Cell Transplantation in Patients with AML}

\author{
Ulla Impola ${ }^{1 *}$, Antti Larjo', Urpu Salmenniemi², Mervi Putkonen², Maija Itälä-Remes ${ }^{2}$ and \\ Jukka Partanen ${ }^{1 *}$
}

${ }^{1}$ Finnish Red Cross Blood Service, Research and Development, Helsinki, Finland, ${ }^{2}$ Turku University Central Hospital, Turku, Finland

Complications of allogeneic hematopoietic stem cell transplantation (HSCT) have been attributed to immune cells transferred into the patient with the graft. However, a detailed immune cell composition of the graft is usually not evaluated. In the present study, we determined the level of variation in the composition of immune cells between clinical HSCT grafts and whether this variation is associated with clinical outcome. Sizes of major immune cell populations in 50 clinical grafts from a single HSCT Centre were analyzed using flow cytometry. A statistical comparison between cell levels and clinical outcomes of HSCT was performed. Overall survival, acute graft-versus-host disease (aGVHD), chronic graft-versus-host disease (cGVHD), and relapse were used as the primary endpoints. Individual HSCT grafts showed considerable variation in their numbers of immune cell populations, including $\mathrm{CD}_{123^{+}}$dendritic cells and $\mathrm{CD} 34^{+}$cells, which may play a role in GVHD. Acute myeloid leukemia (AML) patients who developed aGVHD were transplanted with higher levels of effector $\mathrm{CD}^{+} \mathrm{T}, \mathrm{CD} 19^{+} \mathrm{B}$, and $\mathrm{CD} 123^{+}$dendritic cells than AML patients without aGVHD, whereas grafts with a high $\mathrm{CD} 34^{+}$content protected against aGVHD. AML patients with CGVHD had received grafts with a lower level of monocytes and a higher level of CD34+ cells than those without cGVHD. There is considerable variation in the levels of immune cell populations between HSCT grafts, and this variation is associated with outcomes of HSCT in AML patients. A detailed analysis of the immune cell content of the graft can be used in risk assessment of HSCT.

Keywords: GVHD, AML, transplantation, immune cells

\section{INTRODUCTION}

Allogeneic hematopoietic stem cell transplantation (HSCT) is an established and often the only curative treatment for many malignant hematological diseases. Allogeneic HSCT grafts are harvested from bone marrow (BM) or from peripheral blood (PB) after HSC mobilization and transplanted to the patient in order to reconstitute hematopoiesis and the immune system with the donor's cells and to immunologically kill the recipient's residual cells. Graft-versus-host disease (GVHD) is a severe complication of allogenic HSCT in which the donor's immune cells recognize the patient's tissues as foreign and destroy epithelial and in some cases also endothelial cells. The acute form of 
GVHD (aGVHD) normally occurs within the first 100 days after engraftment, whereas symptoms of chronic GVHD (cGVHD) appear later $(1,2)$. The pathogenesis of GVHD involves complex interactions of cytokines and immune cells; however, the exact mechanism is not completely understood (2-5). The donor's alloreactive effector $\mathrm{T}$ cells and the host's antigen-presenting cells (APCs), such as dendritic cells, have been shown to have an essential role in the initiation of GVHD. Depletion of effector T cells from the HSCT graft decreases the risk of GVHD but at the same time increases the relapse rate, obviously due to insufficient graft-versus-leukemia (GVL) effect $(2,4-6)$.

Studies performed mostly on animal models have demonstrated the role of donor's immune cells in more detail $(5,7-10)$. Effector $\mathrm{T}$ cells, in particular alloreactive $\mathrm{CD} 8^{+} \mathrm{T}$ cells, of the graft are known to have a crucial, direct role in the pathogenesis of $\operatorname{GVHD}(5,11)$. As well as the dose of regulatory T cells (12-14), the balance between the Th1 and Th2 subsets of T cells is thought to be critical in prevention and control of the intensity of GVHD $(5,15)$. Matte et al. showed that the donor's APCs are required for GVHD but not for the GVL effect (16). Furthermore, a high number of B cells in the graft have been reported to associate with the aGVHD risk. B cells most likely present antigens to $\mathrm{T}$ cells and secrete activating cytokines $(17,18)$, whereas monocytes and invariant NKT cells are thought to have an anti-GVHD effect $(8,9)$. The dose per patient kilogram of $\mathrm{CD} 34^{+}$hematopoietic progenitor cells is applied in clinical practice as a high dose of $\mathrm{CD}_{3} 4^{+}$cells is often reported to lead to a better hematopoietic recovery and transplantation outcome, although also conflicting effects are reported and there are contradictory suggestions as an optimal CD34+ dose (19-22). At least in some donor-recipient combinations, natural killer $(\mathrm{NK})$ cells are effective in killing remaining malignant cells and hence decrease the risk of relapse (23-25).

The immune cell composition of the graft is typically not characterized in clinical practice, except for the numbers of CD34 ${ }^{+}$ and $\mathrm{CD}^{+}$cells. Obviously, there is a high level of variation in the cellular composition of the grafts, depending on the donor's background and stem cell collection methods and source (11), although only a few systematic, modern studies have been published (26). To address this question, we analyzed variation in the levels of immune cell populations in 50 clinical HSCT grafts and its impact on the outcome of allogenic HSCT.

\section{MATERIALS AND METHODS}

\section{Patients}

Altogether, 73 allogeneic HSCTs were performed for adult patients in the Turku Central Hospital Hematology Ward and Stem Cell Transplantation Unit during the study period between February 2014 and February 2015. For the present study, we were able to get fresh samples of sufficient size from 50 grafts.

The demographic data of the 50 patients and the 50 HSCTs carried out on them are shown in Table 1. It is of note that one patient, in fact, received two HSCTs, only the first of which was included in the present study. A 46/50 (94\%) patients received a 10-12/12 HLA-matched transplants. Nine (18\%) patients received a graft from a related donor and 39 patients (78\%) from a matched unrelated donor. Two patients (4\%) were transplanted with a graft from a haploidentical (6/12 matched) family donor.

Informed consent was obtained from all patients, and the study protocol was approved by the local Ethical Review Board of the Turku University Hospital, Turku, Finland.

\section{Clinical Protocols, Data, and Endpoints}

The patients were treated with the standard clinical protocols. They were pre-conditioned by using myeloablative chemotherapy (MAC), reduced-intensity conditioning (RIC), or sequential use of intensive chemotherapy (SEQ). The MAC regimen consisted of fludarabine $30 \mathrm{mg} / \mathrm{m}^{2} /$ day for 5 days and busulfan $3.2 \mathrm{mg} / \mathrm{kg} /$ day intravenously for 3-4 days, or, for patients with

\begin{tabular}{|c|c|c|c|c|c|c|c|c|c|c|c|}
\hline Disease & Frequency & $\begin{array}{c}\text { Gender } \\
\text { F/M }\end{array}$ & $\begin{array}{c}\text { Median age } \\
(x-y)\end{array}$ & $\begin{array}{c}\text { Graft source } \\
\text { BM/PB }\end{array}$ & $\begin{array}{l}\text { Conditioning } \\
\text { RIC/MAC (seq.) }\end{array}$ & $\begin{array}{c}\text { IS } \\
\text { cni/mtor }\end{array}$ & $\begin{array}{c}\text { aGVHD/grades } \\
3-4\end{array}$ & $\begin{array}{c}\text { cGVHD } \\
\text { yes/no (ne) }\end{array}$ & Relapse & CMV & $\begin{array}{c}\text { Alive } \\
9 / 2015\end{array}$ \\
\hline ALL & 6 & $5 / 1$ & 32 (19-66) & $1 / 5$ & $1 / 5$ & $4 / 2$ & $3 / 0$ & $2 / 3(1)$ & 1 & 3 & 5 \\
\hline AML & 23 & $10 / 13$ & 57 (29-68) & $5 / 18$ & 10/8 (5) & $6 / 16^{a}$ & $13 / 6$ & 7/12 (4) & 4 & 12 & 15 \\
\hline CLL & 3 & $1 / 2$ & $61(58-61)$ & $0 / 3$ & 2/1 & $1 / 2$ & $3 / 2$ & 2/1 & 0 & 1 & 3 \\
\hline MDS & 3 & $1 / 2$ & 60 (58-63) & $1 / 2$ & $2 / 1$ & $1 / 2$ & $1 / 1$ & $2 / 1$ & 0 & 2 & 2 \\
\hline MF & 1 & $1 / 0$ & 51 & $0 / 1$ & $1 / 0$ & $0 / 1$ & $1 / 1$ & $(1)$ & 1 & 1 & 0 \\
\hline MM & 7 & $4 / 3$ & 55 (43-62) & $0 / 7$ & $3 / 4$ & $2 / 5$ & $5 / 4$ & $5 / 2$ & 0 & 5 & 5 \\
\hline MPN & 1 & $0 / 1$ & 43 & $0 / 1$ & $0 / 1$ & $0 / 1$ & 0 & $(1)$ & 1 & 1 & 0 \\
\hline SAA & 3 & $3 / 0$ & 55 (22-63) & 3 & $4 / 0$ & $3 / 1$ & $3 / 0$ & $1 / 2$ & 1 & 1 & 2 \\
\hline $\mathrm{MbH}$ & 1 & $0 / 1$ & 43 & $0 / 1$ & $0 / 1$ & $0 / 1$ & 0 & $0 / 1$ & 0 & 0 & 1 \\
\hline $\mathrm{NHL}$ & 1 & $0 / 1$ & 24 & $0 / 1$ & $1 / 0$ & $0 / 1$ & 0 & $1 / 0$ & 1 & 0 & 0 \\
\hline T-LBL & 1 & $0 / 1$ & 64 & 0/1 & 0/1 & $0 / 1$ & $1 / 1$ & $1 / 0$ & 1 & 0 & 0 \\
\hline Total & 50 & $25 / 25$ & 55 (19-68) & $10 / 40$ & $24 / 21(5)$ & $17 / 33$ & $30 / 15$ & $21 / 22(7)$ & 9 & 26 & 33 \\
\hline
\end{tabular}

Patient hematological malignancies varied a lot. Primary diseases were acute myelogenous (AML) and lymphoblastic leukemia (ALL), chronic lymphoblastic (CML) and myelomonocytic (MM) leukemia, myelodysblastic syndrome (MDS), myelofibrosis (MF), myeloproliferative neoplasms (MPN), severe aplastic anemia (SAA), Hodgkin (MbH) and non-Hodgkin lymphomas (NHL), and T-cell lymphoblastic lymphoma (T-LBL).

ne, not evaluable.

${ }^{a}$ One patient received steroid treatment. 
ALL, cyclophosphamide $60 \mathrm{mg} / \mathrm{kg} /$ day for 2 days, followed by fractionated total body irradiation $12 \mathrm{~Gy}$. The RIC regimen consisted of fludarabine $30 \mathrm{mg} / \mathrm{m}^{2} /$ day for 5 days and busulfan $3.2 \mathrm{mg} / \mathrm{kg} /$ day intravenously for 2 days. The SEQ conditioning included fludarabine-high dose sytarabine-idarubicine induction, followed by conditioning with cyclophosphamide $60 \mathrm{mg} / \mathrm{kg} /$ day for 2 days and total body irradiation 4 Gy. Rabbit antithymocyte globulin at a dose of $2.5 \mathrm{mg} / \mathrm{kg} /$ day for 2 days together with tacrolimus or everolimus and a short course of methotrexate were used for GVHD prophylaxis.

Clinical data were collected routinely and included in the study during the surveillance period until the end of September 2015. The median follow-up period was 12 months (range 7-19 months). GVHD was defined as either acute (SeattleGlucksberg criteria) (27) or chronic according to the standard criteria and on the basis of the 100-day onset limit, unless the patient had characteristic symptoms of acute GVHD after day 100 (late onset aGVHD).

Acute GVHD was graded from none or mild (grades 0-1) to severe/life-threatening GVHD (grades 2-4) according to Przepiorka et al. (27). Chronic GVHD was classified for statistical analysis as yes or no.

Patient chimerism was tested monthly from whole blood and from the blood T-cell fraction during the post-transplant period and from the $\mathrm{BM} \mathrm{CD} 34^{+}$precursor cell fraction at 2- to 3-month intervals by highly sensitive Abbott AlleleSEQR chimerism assay. Serum cytomegalovirus was monitored weekly during the first 6 months by qPCR.

\section{HSCT Graft Samples}

An aliquot of 3-4 ml was taken from allogeneic HSCT grafts before infusion. The fresh sample was transported to the FRC Blood Service and analyzed within $12 \mathrm{~h}$. Briefly, sample was diluted 1:1 in PBS-EDTA (Invitrogen) supplemented with 2\% (V/V) fetal bovine serum (Gibco), overlaid onto Ficoll-Paque PLUS (GE Healthcare) density gradient medium, and centrifuged in a SepMateTM-15 tube (StemCell Technologies) according to the manufacturer's instructions. The mononuclear cell (MNCs) fraction, buffy coat, was collected and analyzed. Cell viability and the total number of cells were calculated with NucleoCounter before further analysis.

\section{Flow Cytometric Analysis}

Relative proportions of each cell populations in the aliquot of graft sample were analyzed using flow cytometry [FACSAria IIu, Becton Dickinson (BD)] independently at the Finnish Red Cross Blood Service as part of the present study. Cell populations of different main immune cell populations and $\mathrm{CD} 34^{+}$hematopoietic progenitor cells (hereafter "CD34 ${ }^{+}$relat") were identified using combinations of fluorochrome-labeled antibodies (see Table 2). Percent amount of each cell population was calculated as a proportion out of $\mathrm{CD} 45^{+}$cells. Average proportions of lymphocyte and monocyte cell populations were estimated and gated based on their size and granularity.

Antibody-fluorochrome combinations included CD45-PerCpCyanine 5.5, CD3-FITC, CD4-APC-eFluor780, CD11c-APC,
TABLE 2 | Immune cell subpopulations and their surface markers.

\begin{tabular}{|c|c|}
\hline Immune cell subsets & Definition \\
\hline Hematopoietic cells & $\mathrm{CD} 45^{+}$ \\
\hline B cells & $\mathrm{CD}_{45}+, \mathrm{CD} 19^{+}$ \\
\hline Myeloid dendritic cells & 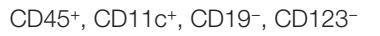 \\
\hline Plasmacytoid dendritic cells & 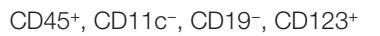 \\
\hline $\mathrm{CD} 4^{+}$progenitor cells & $\mathrm{CD}_{4} 5^{+}, \mathrm{CD}_{3} 4^{+}$ \\
\hline $\mathrm{CD}^{+} \mathrm{T}$ cells & $\mathrm{CD}_{4} 5^{+}, \mathrm{CD}^{+}$ \\
\hline $\mathrm{CD}^{+} \mathrm{T}$ cells & $\mathrm{CD}_{4} 5^{+}, \mathrm{CD}^{+}, \mathrm{CD}^{-}, \mathrm{CD}^{+}$ \\
\hline CD4+ T cells & $\mathrm{CD}_{4} 5^{+}, \mathrm{CD}^{+}, \mathrm{CD}^{+}, \mathrm{CD}^{-}$ \\
\hline CD25+ $\mathrm{T}$ cells & $\mathrm{CD}_{4} 5^{+}, \mathrm{CD}^{+}, \mathrm{CD}^{+}, \mathrm{CD}^{-}, \mathrm{CD}^{2} 5^{+}$ \\
\hline CD3- cells & $\mathrm{CD}_{4} 5^{+}, \mathrm{CD}^{-}$ \\
\hline Natural killer cells & $\mathrm{CD} 45^{+}, \mathrm{CD}^{-}, \mathrm{CD}^{2} 6^{+}, \mathrm{CD}^{2} 6^{+}$ \\
\hline Lymphocytes & $\mathrm{FSC}, \mathrm{SSC}, \mathrm{CD} 45^{+}, \mathrm{CD}^{+}$ \\
\hline Monocytes & FSC, SSC, CD45 ${ }^{+}$ \\
\hline
\end{tabular}

Immune cell subpopulations were identified using combinations of fluorochromelabeled antibodies. Cell populations were gated based on their combination of cell surface markers, cell size, and granularity.

CD16-PE, CD19-FITC, CD25-BV421, CD34-PE, CD56-APC (all from eBiosciences), and CD123-BV421 and CD25-BV421 (Becton Dickinson). Conjugated isotype controls (eBiosciences) and unlabeled cells were used as negative controls. BD Compensation beads were used for signal compensations. Instrument settings and performance were checked using BD's CST Protocol. The FACSDiva ${ }^{\mathrm{TM}}$ Flow Cytometry Software Version 5.02 and FlowJO 7.0 were used for data analysis.

The total number of $\mathrm{CD} 34^{+}$cells in the entire volume of the collected graft (hereafter "CD34+ tot") was measured in the stem cell collecting centers during harvesting of the graft. In our sample, cohort the median total, number of $\mathrm{CD} 4^{+}$cells was $1.48 \times 10^{8}$ cells $/ \mathrm{l}$ in BM- and $5.82 \times 10^{8}$ cells $/ \mathrm{l}$ in PB-derived grafts. The total number of $\mathrm{CD} 34^{+}$cells $\times 10^{8} / 1$ was used for the determination of clinical dose $\left(\mathrm{CD} 34^{+}\right.$dose, number of $\mathrm{CD} 34^{+}$ cells per recipient weight).

\section{Colony Forming Unit Assay}

The Colony Forming Unit (CFU) assay estimates the number and potency of hematopoietic progenitors. The assay was performed according to the manufacturer's instructions (MethoCult ${ }^{\mathrm{TM}}$ Media, StemCell Technologies). Cell colonies were counted on days 13 and 18, and triplicates were used in calculations.

\section{Statistical Analysis}

Statistical tests on associations between levels of cell populations in grafts and clinical endpoints were mainly carried out using Wilcoxon rank-sum test and Fisher's exact test, and other tests as described in the text. As multivariate analysis was not meaningful due to low numbers of cases in some groups, we instead used random forest classifiers to assess how well the clinical endpoints could be predicted using the measured cell populations while also including other possibly influencing factors. $\mathrm{R}$ and caret package (28-30) were used for statistical analyses. All cell populations, as well as HLA match, graft type, immunosuppressive medication, pre-conditioning, and donor type, were used as potential predictors, and the accuracies were estimated using fourfold crossvalidation repeated 100 times. Within each clinical endpoint, 
we ranked (from 0 to 100) the importance of the parameter as a predictor. These rankings were used along with the nominal $p$-values to estimate the significance of the findings. It is of note that the results are based on a limited set of data points and the classifiers have not been tested with real held-out dataset, so the reported performances (Table S1 in Supplementary Material) may be over-optimistic.

\section{RESULTS}

\section{Clinical Outcomes}

The demographic data of the patients are summarized in Table $\mathbf{1 .}$ During the study period, 17 of the 50 patients died (overall survival $66 \%$, transplantation related mortality $24 \%$ ). Patients who received stem cell graft from an HLA-matched sibling donor had a better overall survival than those who received an unrelated HSCT ( $p=0.039$ ). No other statistically significant association was found between clinical endpoints and the donor type. The HLA match showed no statistically significant association with clinical endpoints (data not shown).

Acute GVHD was diagnosed in 30 of the 50 patients (60\%), 15 of whom had severe grades 3-4 aGVHD while 15 had grades 1-2 aGVHD. Chronic GVHD was classified as yes/no, and even very mild symptoms were included to the positive group. This might explain rather high incidence of cGVHD among our patients as twenty-one (42\%) had cGVHD. Nine of the 50 patients (18\%) had a relapse during the surveillance period. Serum cytomegalovirus was found in 26 of the 50 patients (52\%).

\section{Variation between BM and PB Grafts}

The grafts originated from BM in 10 HSCTs (20\%) and from PB in 40 HSCTs (80\%). We compared the differences in the proportional shares, i.e., not absolute numbers, of immune cell populations between these two types of grafts (Figure 1A). BM-derived grafts contained higher levels of lymphocytes $(p=0.008), \mathrm{CD}^{+}$ cells $\left(p=4.3 \times 10^{-6}\right)$, and CD19+ B cells $(p=0.009)$ than the PB-derived grafts. $\mathrm{PB}$-derived grafts had a significantly higher level of monocytes $\left(p=2.4 \times 10^{-10}\right)$ than the BM grafts. The graft type as such was not found to be associated with the clinical endpoints.

\section{Variation between Individual Grafts}

The levels of immune cell subpopulations varied between individual stem cell grafts (Figures 1B-D). Figure 1B shows the variation of all cell populations, and Figure 1C shows the variation in the effector subsets of $\mathrm{CD}^{+}$cells and in NK cells. Figure 1D shows the change in the levels of B cells, CD34 ${ }^{+}$cells, and two types of dendritic cells (CD11 ${ }^{+}$and $\mathrm{CD}_{123^{+}}$cells). The levels of many cell populations known to be relevant to the outcome of HSCT showed variation between the grafts. The highest coefficients of variation (variability in relation to the mean of the measurement) were seen for the levels of $\mathrm{CD} 34^{+}$progenitor cells, $\mathrm{CD}_{123^{+}}$plasmacytoid and $\mathrm{CD} 11 \mathrm{c}^{+}$myeloid dendritic cells, and $\mathrm{CD} 19^{+} \mathrm{B}$ cells. On the other hand, $\mathrm{CD}^{+}$and $\mathrm{CD} 8^{+} \mathrm{T}$-cell populations had low coefficients of variation (data not shown).

\section{Association of Variation in the Graft Cell Populations with Clinical Endpoints}

Association analyses between the clinical endpoints and levels of immune cells in the grafts were performed. As multivariant analysis was not meaningful due to low numbers of cases in some groups, we instead used random forest classifiers to assess how well the clinical endpoints could be predicted using the measured cell populations while also including other possibly influencing factors. Hence, classifiers were built to find how important each cell population is for predicting clinical outcomes. The best classification accuracies were obtained in Acute myeloid leukemia (AML) cases for cGVHD (AUC 0.86), relapse (AUC 0.81), and aGVHD (AUC 0.78).

When all diagnoses were included, none of the classifiers achieved a very high performance (maximum AUC 0.73), possibly indicating high heterogeneity in the diseases. All results are summarized in Table S1 in Supplementary Material.

When all HSCTs were included, a low "CD34 tot" level in the graft was associated with the cytomegalovirus positivity (Figure 2; $p=0.04)$. In addition, an association was observed between a low level of "CD34+ relat" and the occurrence of cGVHD $(p=0.022)$ among the patients $(N=10)$ who received a BM graft. A low level of $\mathrm{CD} 25^{+} \mathrm{CD} 4{ }^{+} \mathrm{T}$ cells, a population containing regulatory T cells, was associated with the occurrence of relapse $(p=0.041)$ and rejection $(p=0.032)$ (data not shown).

To reduce heterogeneity of the patient group, we analyzed the largest single patient group, AML, separately $(N=23$ of the 50 patients). A low "CD34+ tot" level in the graft (Figure 3A; $p=0.014$ ) and a low $\mathrm{CD} 4^{+}$dose (cells/kg; Figure $3 \mathrm{~B} ; p=0.015$ ) were both associated with the occurrence of aGVHD in the AML patients. The association remained statistically significant regardless of conditioning (data not shown).

Acute myeloid leukemia patients with grades 2-4 aGVHD had received grafts with higher levels of $\mathrm{CD}^{+} \mathrm{T}$ lymphocytes than those without aGVHD (Figure 4A; $p=0.007$ ). In fact, there was a clear trend between the levels of $\mathrm{CD}^{+}$cells and the severity of aGVHD (Figure 4B; $p=0.028$; Kruskal-Wallis test). Occurrence of grades 2-4 aGVHD in AML patients was associated with high levels of many effector immune cells in the graft: $\mathrm{CD} 4^{+}$cells (Figure 4C; $p=0.039$ ), $\mathrm{CD}^{+}$cells (Figure 4D; $p=0.032$ ), CD19+ cells (Figure 4E; $p=0.044$ ), and $\mathrm{CD}_{123^{+}}$(Figure 4F; $p=0.011$ ). Of these, particularly $\mathrm{CD}^{+}$and $\mathrm{CD} 123^{+}$ranked high as predictors, attesting to the prominence of their role.

Acute myeloid leukemia patients with cGVHD had received HSCT grafts containing lower levels of monocytes (Figure 5A; $p=0.005$ ) and higher levels of "CD34+relat" (Figure 5B; $p=0.01)$ than those without cGVHD. Monocytes were ranked as the most important predictor for cGVHD, indicating that they play a major role.

\section{DISCUSSION}

Graft-versus-host disease remains a major challenge in allogeneic HSCT. The mechanism of GVHD is complex and depends on many factors, particularly on the interactions of various immune 


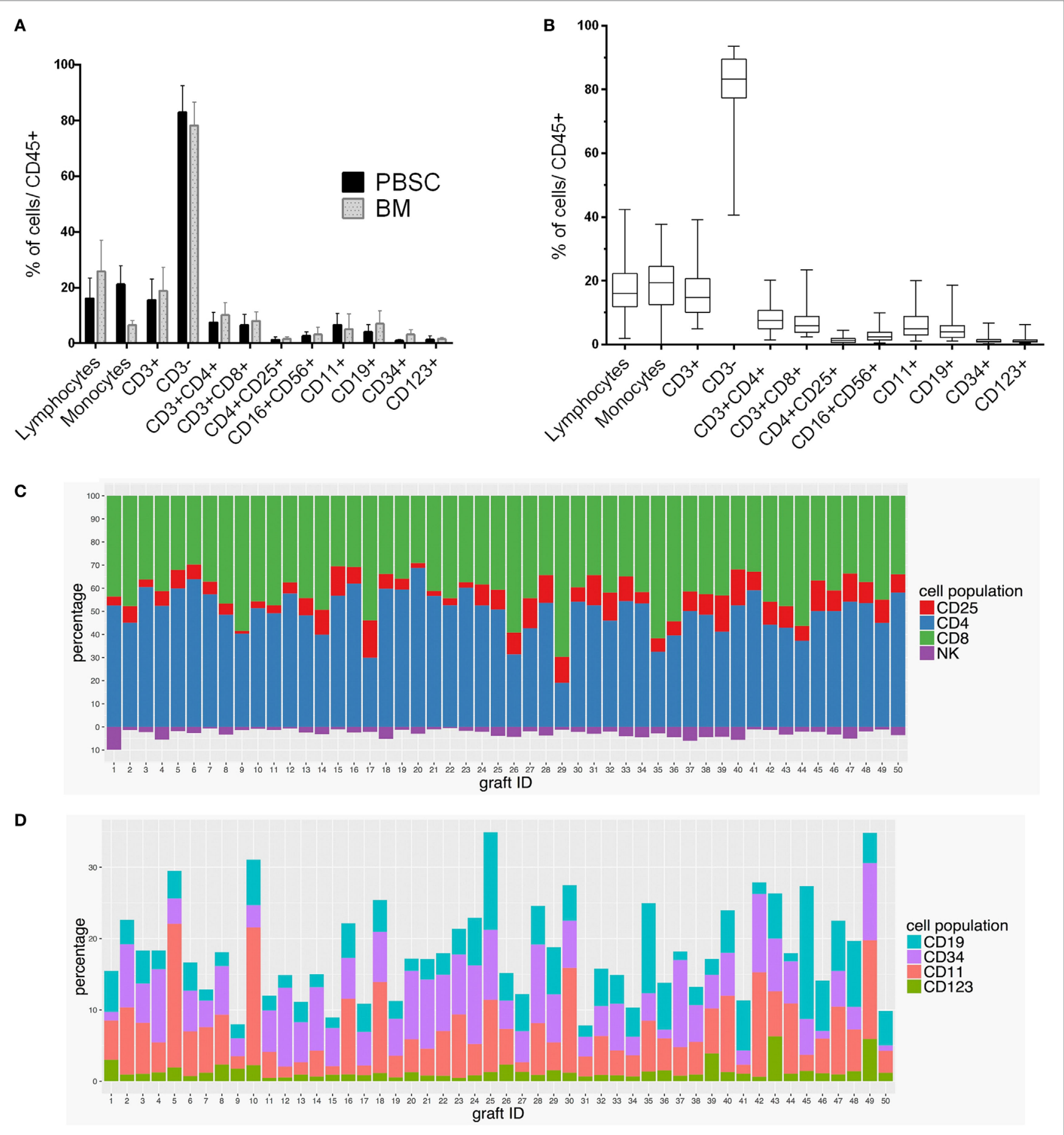

FIGURE 1 | Variation of immune cell subpopulations in HSCT grafts. The composition of immune cell populations varied (A) among BM and PB grafts and (B) in individual 50 clinical HSCT grafts as measured by the percentages of the cell populations in graft samples. (C) Levels of $\mathrm{CD}^{+}, \mathrm{CD}^{+}, \mathrm{CD}^{+}, \mathrm{CD}^{+} \mathrm{CD}^{+} 5^{+}, \mathrm{CD}^{16} 6^{+}$

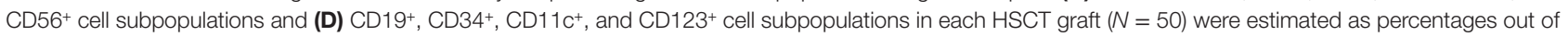
$\mathrm{CD} 45^{+}$cells. Lymphocytes and monocytes were identified based on their size and granularity.

cell populations and on the donor's $\mathrm{T}$ cells that are transferred along with the allograft and which attack host tissues (5). Hence, it is plausible that the composition of immune cells in the clinical
HSCT graft also influence the outcome. However, current clinical HSCT protocols usually rely on counting from the graft only the numbers of nucleated cells and $\mathrm{CD} 34^{+}$hematopoietic stem cells, 
with estimates of $\mathrm{CD}^{+} \mathrm{T}$ lymphocytes sometimes included. No detailed analysis of cellular content of the graft is performed. To address the role of immune cell composition of the graft, in more detail, we studied systematically 50 clinical HSCT grafts for their immune cell composition and its influence on the clinical outcome of HSCT.

First, we found that there was considerable variation between individual grafts in regard to levels of many cell populations that, based on models of GVHD pathogenesis $(3,5,10,31)$, can be assumed to influence the clinical outcome of HSCT, such as the severity of GVHD or incidence of relapse. Second, we present evidence that this variation in levels of certain cell populations, in particular levels of effector immune cells, is significantly associated with the grade and type of GVHD. The effect was clearer in a subgroup of patients, those with AML, suggesting

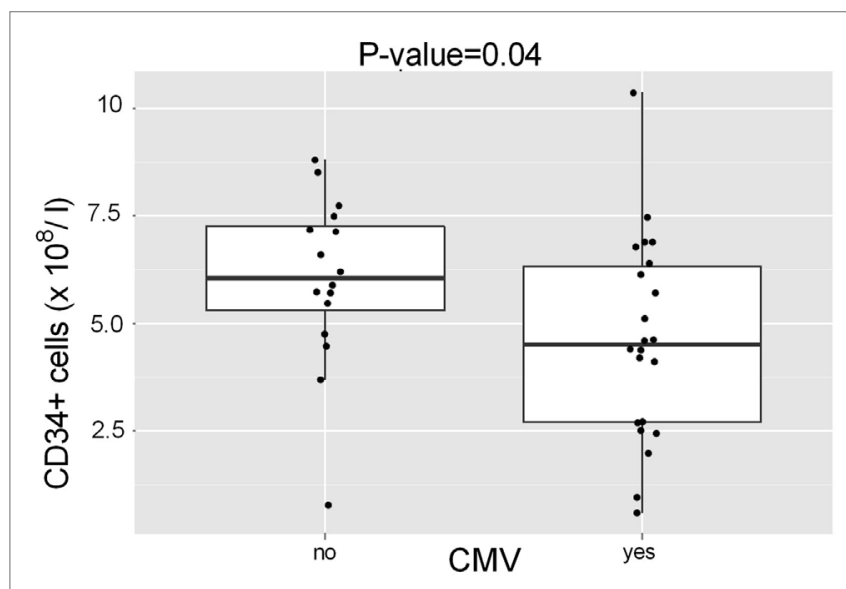

FIGURE 2 | Association of CD34+ cell numbers in the HSCT grafts with serum cytomegalovirus. Patients $(N=26)$ with serum cytomegalovirus had received HSCT grafts that contained lower total number of $\mathrm{CD}_{3} 4^{+}$cells $\left(\mathrm{CD} 34^{+}\right.$tot, median $\left.5.3 \times 10^{8} / \mathrm{I}\right)$ than those with no detected cytomegalovirus $(N=24) p=0.04$. that the underlying disease and its treatment should be taken into account.

There are only a few recent publications $(11,26,32,33)$ describing systematically variation in the levels of immune cell populations in clinical HSCT grafts. Many studies have concentrated on the effects of stem cell mobilizing regimens on immune cell levels. In these studies, differences were reported in the numbers of $\mathrm{T}$ lymphocytes and their Th1/Th2 balance (34) and NK cells and dendritic cells $(11,35,36)$. Recent studies $(9,37)$ found that mobilization induced particular subpopulations of monocytes that may regulate GVHD. In our present study, we observed the highest levels of variation in $\mathrm{CD} 34^{+}$ hematopoietic cells, $\mathrm{CD} 123^{+}$plasmacytoid and $\mathrm{CD} 11 \mathrm{c}^{+}$myeloid dendritic cells, $\mathrm{CD} 19^{+} \mathrm{B}$ cells, and $\mathrm{CD} 4{ }^{+} \mathrm{CD} 25^{+} \mathrm{T}$ cells; all these cell populations can be assumed to play a role in GVHD, GVL, or relapse. As an example, the levels of $\mathrm{CD} 11^{+}$positive dendritic cells differed up to 10 -fold between individual grafts. As relatively small numbers of dendritic cells can activate the immune response by presenting peptide antigens to naïve $\mathrm{T}$ cells, the differences observed here could be immunologically relevant $(38,39)$.

Only a few studies have directly addressed the origin of variation in immune cell numbers. It is obviously possible that genetic factors, such as HLA genes or interleukin-2 receptor A gene, determine the size of at least some immune and blood cell populations as reported by e.g., Orrú et al. (40). Orrú et al. concluded that heritability accounted for up to $87 \%$ of the variation in immune cell levels (40). However, Brodin et al. reported (41) based on a twin study that in fact, non-heritable factors, such as immunological history and vaccinations, were the major drivers of variation in the human immune system. How much these studies can be extended to clinical HSCT grafts is unclear.

The origin of the HSCT graft, BM versus $\mathrm{PB}$ is an obvious source of variation in cell content. $\mathrm{PB}$ has become widely used as a stem cell source, almost replacing the use of BM in allogeneic HSCT in some centers (35). In the present study, $20 \%$ of the grafts
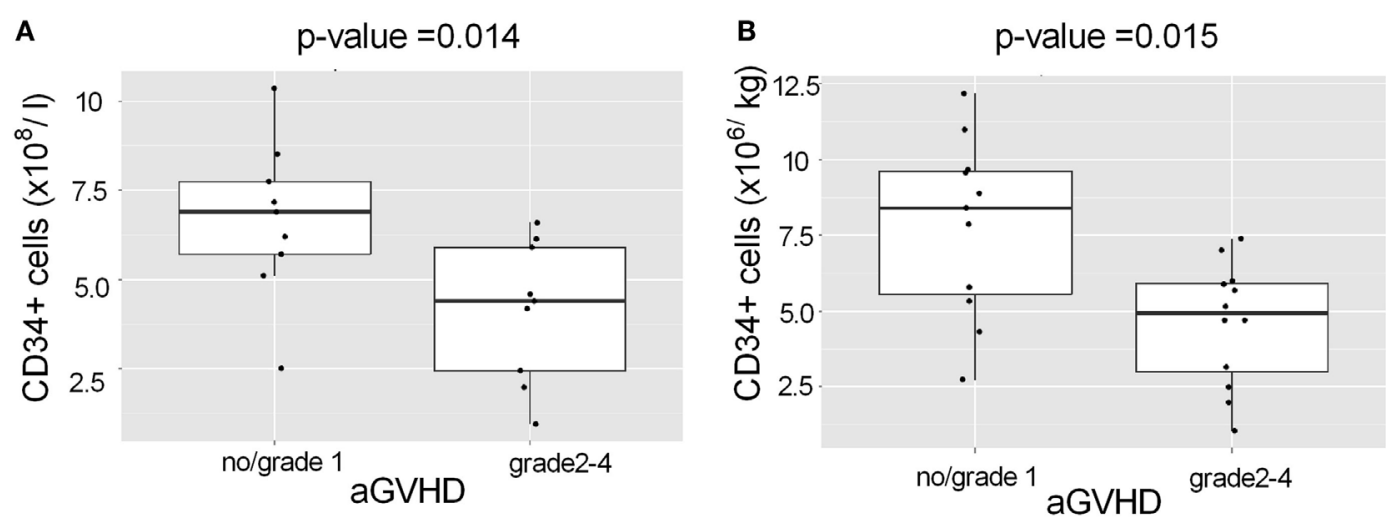

FIGURE 3 | Association of CD34+ cell levels in the HSCT grafts with aGVHD among AML patients. AML patients with grades $2-4$ aGVHD had received HSCT grafts $(\mathbf{A})$, which contained a lower total number of CD34+ cells $(p=0.014)$ and $(\mathbf{B})$ a lower dose of CD34 ${ }^{+}$cells $/ \mathrm{kg}(p=0.015)$ than AML patients with grade 1 or no aGVHD. The median dose of CD34+ cells $/ \mathrm{kg}$ of recipient was $5.7 \times 10^{6} / \mathrm{kg}$. 

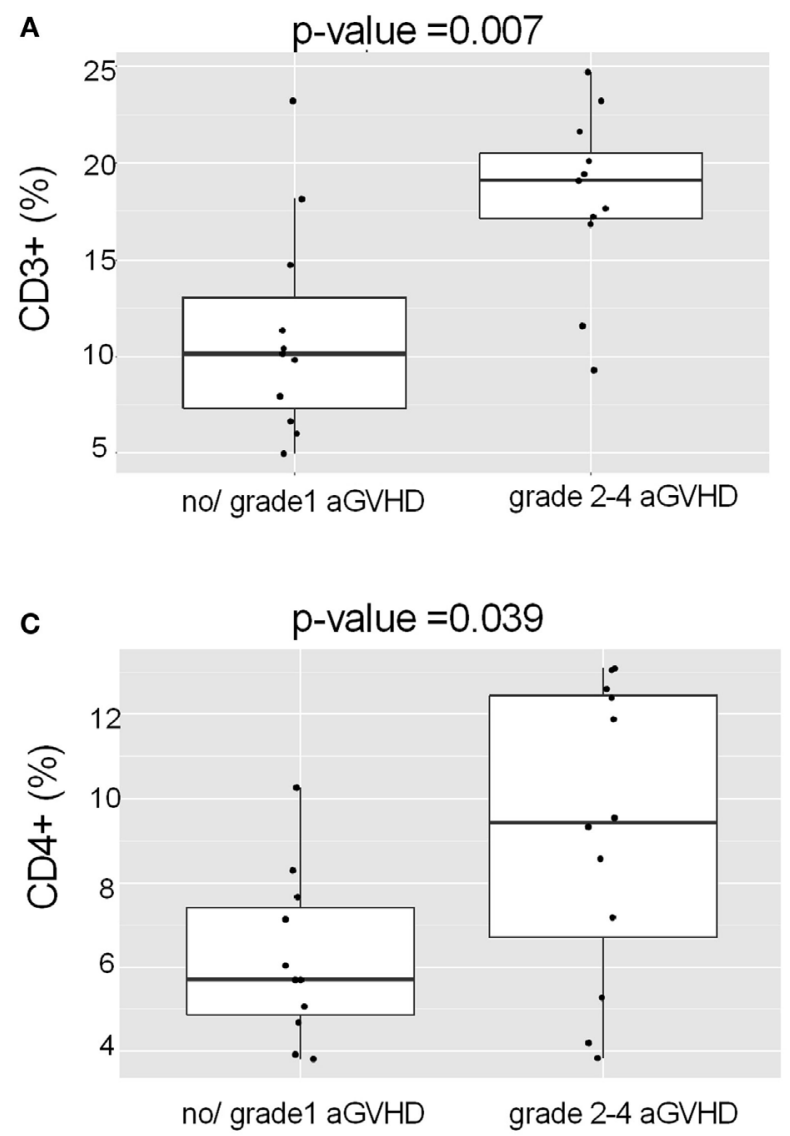

E

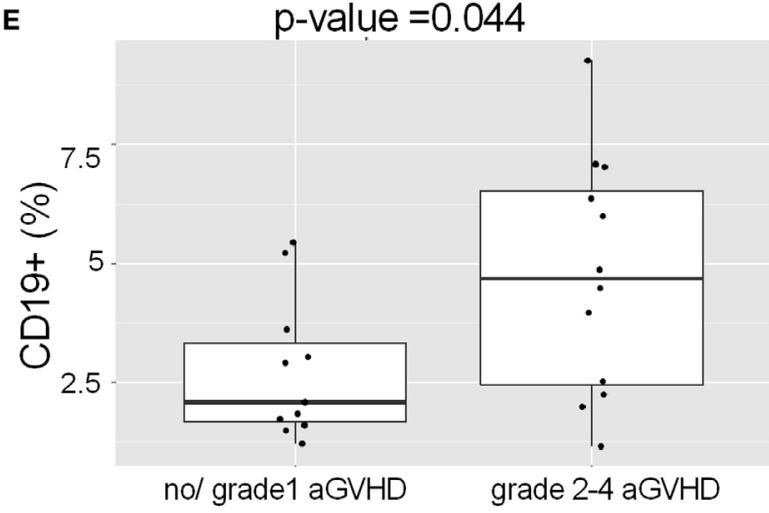

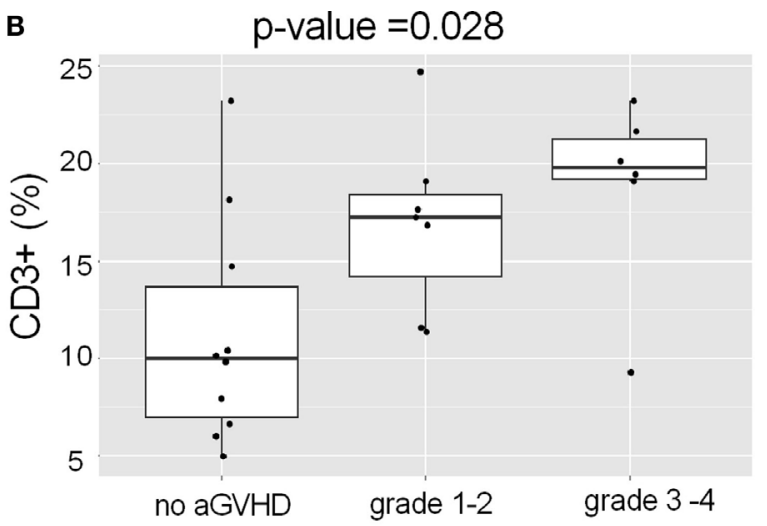

D

p-value $=0.032$

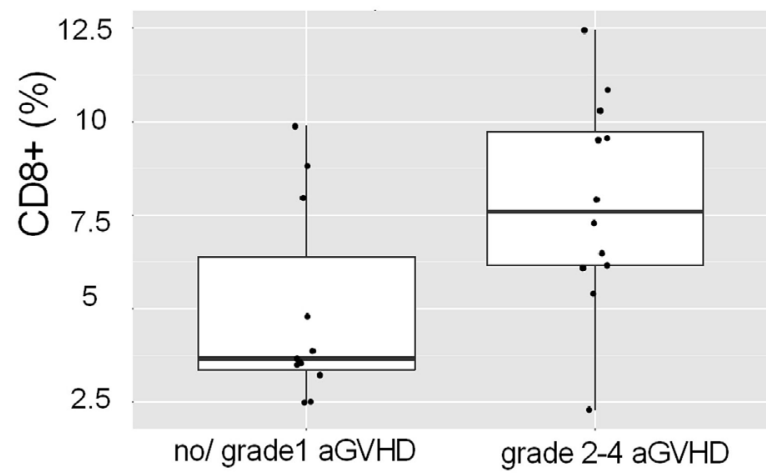

$\mathbf{F}$

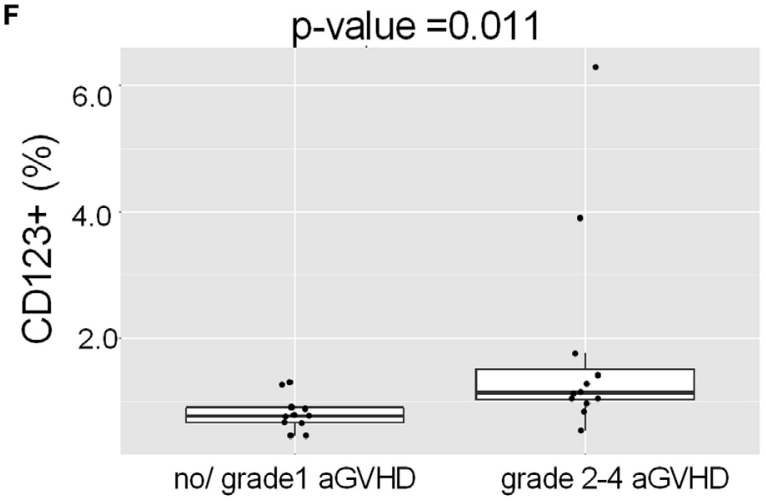

FIGURE 4 | Association of the graft proportions of CD3 $3^{+}$lymphocytes, CD19+ and CD123+ cells with acute GVHD in AML patients. (A) AML patients with grades 2-4 aGVHD had received grafts with higher levels of $C D 3^{+}$cells than patients with grade 1 or no aGVHD $(p=0.007)$. (B) Patients with AML showed a trend $(p=0.028$, Kruskal-Wallis test) toward more severe aGVHD along with the increasing levels of CD3+ cells in the graft. AML patients with grades $2-4$ aGVHD had received HSCT grafts with higher levels of $(\mathbf{C}) \mathrm{CD}^{+}$, (D) $\mathrm{CD} 8^{+}$, (E) $\mathrm{CD} 19^{+}$, and (F) $\mathrm{CD} 123^{+}$cells as compared to those with grade 1 or no aGvHD. All proportions are calculated as \%/CD45+ cells.

originated from $\mathrm{BM}$ and the rest were harvested from mobilized $\mathrm{PB}$. The PB-derived grafts had a significantly higher level of monocytes than BM-derived grafts; this finding is in line with those by Korbling and Freireich (35) and Ottinger et al. (42). The BM-derived grafts of the present study contained higher levels of lymphocytes, $\mathrm{CD} 19^{+} \mathrm{B}$ cells, and $\mathrm{CD} 34^{+}$cells. The higher level of
$\mathrm{CD}^{+}{ }^{+}$cells in BM has been established earlier (43), whereas B cells have been reported to be more frequent in $\mathrm{PB}$ than in $\mathrm{BM}$ $(43,44)$.

The variation in the cell levels between the grafts was found to influence the clinical outcome of HSCT. It is of interest that the highest level of variation in the present study was seen in the 

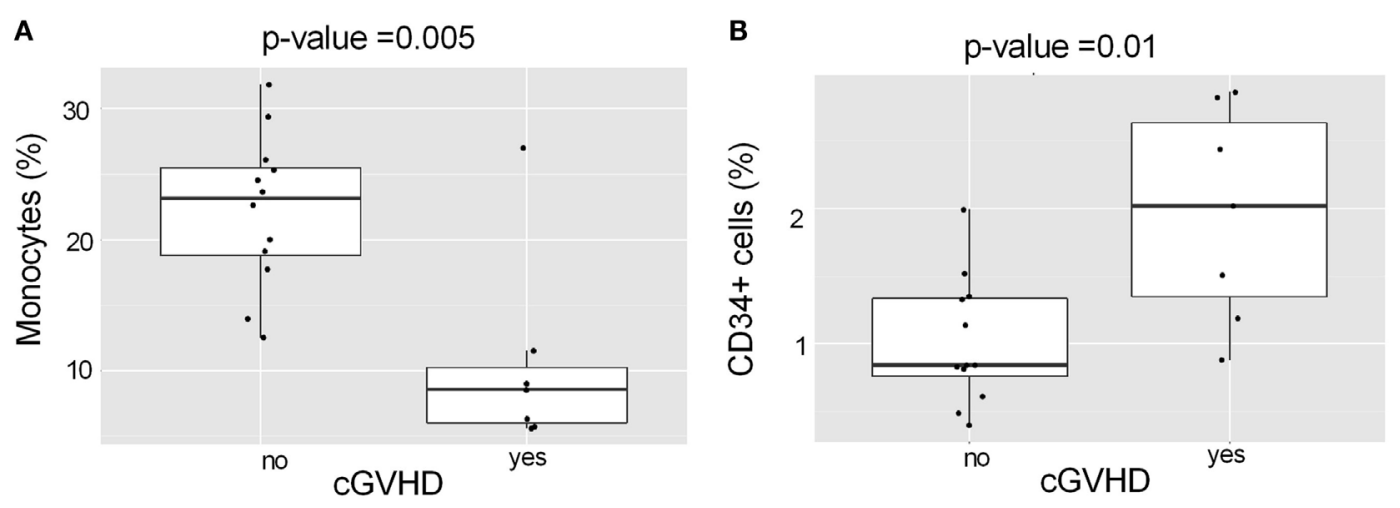

FIGURE 5 | Association of monocyte and CD34+ cell levels in the HSCT grafts with chronic GVHD in AML patients. (A) AML patients with cGVHD had received HSCT grafts with lower levels of monocytes than AML patients without cGvHD $(p=0.005)$. (B) AML patients with cGVHD had received HSCT grafts with higher levels of CD34+ cells than those without cGVHD $(p=0.01)$.

number of $\mathrm{CD} 4^{+}$hematopoietic cells, the very same population that appears to be one of the major determinants of the outcome of HSCT. The median total number of $\mathrm{CD} 34^{+}$cells in $\mathrm{BM}$ grafts was in the present study about fourfold lower than that in PB-derived grafts. However, the relative proportion of CD34 ${ }^{+}$ cells in BM samples was clearly higher compared to PB grafts. We found that high levels of $\mathrm{CD} 34^{+}$cells in the graft protected from severe aGVHD but predisposed to CGVHD in AML patients and protected from serum cytomegalovirus in all patients. A high dose of $\mathrm{CD}_{3} 4^{+}$cells has been reported to lead to a better hematopoietic recovery, however not always to a better transplantation outcome $(19,20,22)$ Conflicting data is presented also in other studies $(21,45)$. Our finding that a high $\mathrm{CD}_{3} 4^{+}$cell content in the graft predisposed to cGVHD may be related to $\mathrm{CD} 34^{+}$-derived dendritic cells that have been reported to be able to augment antigen presentation to donor T cells and induce cGVHD (46). It is of note that according to a recent study by Martin et al. (47), estimates of the total number of nucleated cells, especially CD34 negative cells, might in fact be better predictors of HSCT outcome than the $\mathrm{CD}_{3} 4^{+}$cell dose at least in HSCT performed using RIC and $\mathrm{PB}$.

Another major finding in the present study was the association of high levels of many effector cell populations, such as $\mathrm{CD}^{+}, \mathrm{CD}^{+}$, and $\mathrm{CD} 8^{+} \mathrm{T}$ cells or $\mathrm{CD} 19^{+} \mathrm{B}$ cells, in the HSCT grafts with the more severe aGVHD in AML patients. In addition, AML patients with severe aGVHD had received higher levels of plasmacytoid $\mathrm{CD}_{123^{+}}$dendritic cells (pDCs) in the grafts than those without or with grade 1 aGVHD. The association of high levels of effector cell populations with more severe aGVHD is not surprising as it is assumed that many effector cell populations of donor-origin are involved in the pathogenesis of aGVHD $(1,5,15)$. There is an abundance of evidence on the role of $\mathrm{T}$ cells as initiators of aGVHD. Also, as mediators of antitumor immunity, $\mathrm{CD}^{+}$cells, when present in high doses, are known to be associated with a lower risk for relapse (48), but we could not verify this in the present study. High regulatory $\mathrm{T}$ cell doses are known to control GVHD while still allowing active GVL effect $(12,13,49,50)$. We found some evidence indicating that low doses of $\mathrm{CD} 4^{+} \mathrm{CD} 25^{+} \mathrm{T}$ cells, a population including regulatory $\mathrm{T}$ cells, were associated with higher risks for relapse and rejection.

The possible role of pDCs in inducing aGVHD is interesting, but so far these cells have not been studied extensively in this context $(26,51)$. pDCs constitute a multifunctional cell type involved e.g., in production of type-I interferons against virus infections, induction of Th17 cell response, and presentation of peptide antigens by MHC class II to T cells (52). High levels of pDCs in the graft can lead to immune activation as pDCs may more readily detect, via their toll-like receptors, the tissue damage caused by pre-transplantation conditioning. Then, they may become activated and act as APC. However, experimental data for this is still scarce $(51,53)$. Peric et al. recently reported that high levels of $\mathrm{pDC}$ post-HSCT predicted good clinical outcome with less severe GVHD and better overall survival (53). Waller and coworkers (26) found that survival was better in HSCTs with high pDCs. More research on the role of pDCs in GVHD is clearly warranted.

Clinical presentation of cGVHD resembles fibrotic autoimmune disorders and involves Th2 and B cells (54), cytokines secreted by Th1 cells (55), Th17 cells, and autoantibodies (54). Also, a low number of active regulatory $\mathrm{T}$ cells (56) have previously been associated with cGVHD. The levels of regulatory $\mathrm{T}$ cells or B cells in the graft were not associated with cGVHD in the present study. However, we found that low levels of CD $34^{+}$ cells and monocytes in the graft were associated with cGVHD in $\mathrm{AML}$ patients. The $\mathrm{CD}^{+} 4^{+}$and monocyte populations can be regarded as a source of dendritic cells (57), which can efficiently present antigens to donor T cells and may, therefore, be involved in the induction of cGVHD. Our finding that various cell populations in the grafts were found to be associated with the development of aGVHD, as opposed to cGVHD, supports distinct immunological background and pathogenesis between the two types of GVHD.

The present study demonstrates a considerable variation of the cellular content in the HSCT graft which might affect patient outcome depending on their diagnosis. In addition to 
the numbers of $\mathrm{CD}_{3} 4^{+}$and $\mathrm{CD}^{+}$cells, a more detailed profiling of graft immune cells and their proportions might provide beneficial knowledge of cell populations that play a role in the pathogenesis of GVHD. This could be applied in risk assessments in HSCT and support the development of more personalized transplantation protocols.

\section{AUTHOR CONTRIBUTIONS}

UI, MI-R, and JP designed the research; MP, US, and MI-R treated the patients and collected the samples and clinical data; UI performed laboratory analyses with flow cytometry; AL did statistical analysis; UI, AL, JP, and MI-R interpreted the results; and UI, AL, JP, and MI-R wrote the manuscript.

\section{REFERENCES}

1. Sung AD, Chao NJ. Concise review: acute graft-versus-host disease: immunobiology, prevention, and treatment. Stem Cells Transl Med (2013) 2(1):25-32. doi:10.5966/sctm.2012-0115

2. Ferrara JL. Pathogenesis of acute graft-versus-host disease: cytokines and cellular effectors. J Hematother Stem Cell Res (2000) 9(3):299-306. doi:10.1089/15258160050079407

3. Ferrara JL, Cooke KR, Teshima T. The pathophysiology of acute graft-versushost disease. Int J Hematol (2003) 78(3):181-7. doi:10.1007/BF02983793

4. Wolf $\mathrm{D}$, von Lilienfeld-Toal $\mathrm{M}$, Wolf AM, Schleuning M, von BergweltBaildon M, Held SA, et al. Novel treatment concepts for graft-versus-host disease. Blood (2011) 119(1):16-25. doi:10.1182/blood-2011-08-339465

5. Blazar BR, Murphy WJ, Abedi M. Advances in graft-versus-host disease biology and therapy. Nat Rev Immunol (2012) 12(6):443-58. doi:10.1038/ nri3212

6. Shlomchik WD, Couzens MS, Tang CB, McNiff J, Robert ME, Liu J, et al. Prevention of graft versus host diseaseby inactivation of host antigen-presenting cells. Science (1999) 285(5426):412-5. doi:10.1126/science.285.5426.412

7. Yakoub-Agha I, Saule P, Depil S, Grutzmacher C, Boulanger F, Magro L, et al. Comparative analysis of naive and memory $\mathrm{CD}^{+}$and $\mathrm{CD} 8^{+} \mathrm{T}$-cell subsets in bone marrow and G-CSF-mobilized peripheral blood stem cell allografts: impact of donor characteristics. Exp Hematol (2007) 35(6):861-71. doi:10.1016/j.exphem.2007.03.006

8. Chaidos A, Patterson S, Szydlo R, Chaudhry MS, Dazzi F, Kanfer E, et al. Graft invariant natural killer T-cell dose predicts risk of acute graft-versus-host disease in allogeneic hematopoietic stem cell transplantation. Blood (2012) 119(21):5030-6. doi:10.1182/blood-2011-11-389304

9. Fraser AR, Cook G, Franklin IM, Templeton JG, Campbell M, Holyoake $\mathrm{TL}$, et al. Immature monocytes from G-CSF-mobilized peripheral blood stem cell collections carry surface-bound IL-10 and have the potential to modulate alloreactivity. J Leukoc Biol (2006) 80(4):862-9. doi:10.1189/ jlb.0605297

10. Boieri M, Shah P, Dressel R, Inngjerdingen M. The role of animal models in the Study of Hematopoietic Stem Cell Transplantation and GvHD: a historical overview. Front Immunol (2106) 7:333. doi:10.3389/fimmu.2016.00333

11. Saraceni F, Shem-Tov N, Olivieri A, Nagler A. Mobilized peripheral blood grafts include more than hematopoietic stem cells: the immunological perspective. Bone Marrow Transplant (2015) 50(7):886-91. doi:10.1038/ bmt.2014.330

12. Pastore D, Delia M, Mestice A, Carluccio P, Perrone T, Gaudio F, et al. $\mathrm{CD}^{+}{ }^{+}$ Tregs ratio in donor grafts is linked to acute graft-versus-host disease and immunologic recovery after allogeneic peripheral blood stem cell transplantation. Biol Blood Marrow Transplant (2012) 18(6):887-93. doi:10.1016/ j.bbmt.2011.10.039

13. Delia M, Pastore D, Mestice A, Carluccio P, Perrone T, Gaudio F, et al. Outcome of allogeneic peripheral blood stem cell transplantation by donor graft $\mathrm{CD}^{+} /$ Tregs ratio: a single-center experience. Biol Blood Marrow Transplant (2013) 19(3):495-9. doi:10.1016/j.bbmt.2012.11.015

\section{ACKNOWLEDGMENTS}

The authors thank Lotta Andersson for excellent technical help and the personnel of Finnish Red Cross Blood Service Stem Cell Registry and Turku University Central Hospital Haematology Ward and Stem Cell Transplantation Unit and patients for the collaboration. This study was partially supported by the State Research Funding from the Finnish Government.

\section{SUPPLEMENTARY MATERIAL}

The Supplementary Material for this article can be found online at http://journal.frontiersin.org/article/10.3389/fimmu. 2016.00523/full\#supplementary-material.

14. Nguyen VH, Shashidhar S, Chang DS, Ho L, Kambham N, Bachmann M, et al. The impact of regulatory $\mathrm{T}$ cells on T-cell immunity following hematopoietic cell transplantation. Blood (2008) 111(2):945-53. doi:10.1182/ blood-2007-07-103895

15. Ferrara JL. Cellular and cytokine effectors of acute graft versus host disease. Int J Hematol (2002) 76(Suppl 1):195-8. doi:10.1007/BF03165244

16. Matte CC, Liu J, Cormier J, Anderson BE, Athanasiadis I, Jain D, et al. Donor APCs are required for maximal GVHD but not for GVL. Nat Med (2004) 10(9):987-92. doi:10.1038/nm1089

17. Iori AP, Torelli GF, De Propris MS, Milano F, Pupella S, Gozzer M, et al. $\mathrm{B}$-cell concentration in the apheretic product predicts acute graft-versushost disease and treatment-related mortality of allogeneic peripheral blood stem cell transplantation. Transplantation (2008) 85(3):386-90. doi:10.1097/ TP.0b013e3181622e36

18. Shimabukuro-Vornhagen A, Hallek MJ, Storb RF, von Bergwelt-Baildon MS. The role of $\mathrm{B}$ cells in the pathogenesis of graft-versus-host disease. Blood (2009) 114(24):4919-27. doi:10.1182/blood-2008-10-161638

19. Stiff PJ, Micallef I, Nademanee AP, Stadtmauer EA, Maziarz RT, Bolwell BJ, et al. Transplanted CD34(+) cell dose is associated with long-term platelet count recovery following autologous peripheral blood stem cell transplant in patients with non-Hodgkin lymphoma or multiple myeloma. Biol Blood Marrow Transplant (2011) 17(8):1146-53. doi:10.1016/j.bbmt.2010.11.021

20. Gómez-Almaguer D, Gómez-Peña Á, Jaime-Pérez JC, Gómez-Guijosa MÁ, Cantú-Rodríguez $\mathrm{O}$, Gutiérrez-Aguirre $\mathrm{H}$, et al. Higher doses of CD34 ${ }^{+}$ progenitors are associated with improved overall survival without increasing GVHD in reduced intensity conditioning allogeneic transplant recipients with clinically advanced disease. J Clin Apher (2013) 28(5):349-55. doi:10.1002/ jca. 21278

21. Remberger M, Torlen J, Ringden O, Engstrom M, Watz E, Uhlin M, et al. Effect of total nucleated and $\mathrm{CD} 34^{(+)}$cell dose on outcome after allogeneic hematopoietic stem cell transplantation. Biol Blood Marrow Transplant (2015) 21(5):889-93. doi:10.1016/j.bbmt.2015.01.025

22. Siena S, Schiavo R, Pedrazzoli P, Carlo-Stella C. Therapeutic relevance of CD34 cell dose in blood cell transplantation for cancer therapy. J Clin Oncol (2000) 18(6):1360-77. doi:10.1200/jco.2000.18.6.1360

23. Kalinski P, Mailliard RB, Giermasz A, Zeh HJ, Basse P, Bartlett DL, et al. Natural killer-dendritic cell cross-talk in cancer immunotherapy. Expert Opin Biol Ther (2005) 5(10):1303-15. doi:10.1517/14712598.5.10.1303

24. Moretta L, Pietra G, Montaldo E, Vacca P, Pende D, Falco M, et al. Human NK cells: from surface receptors to the therapy of leukemias and solid tumors. Front Immunol (2014) 5:87. doi:10.3389/fimmu.2014.00087

25. Ruggeri L, Capanni M, Urbani E, Perruccio K, Shlomchik WD, Tosti A, et al. Effectiveness of donor natural killer cell alloreactivity in mismatched hematopoietic transplants. Science (2002) 295(5562):2097-100. doi:10.1126/ science. 1068440

26. Waller E, Logan B, Harris W, Devine S, Porter D, Mineishi S, et al. Improved survival after transplantation of more donor plasmacytoid dendritic or naïve $\mathrm{T}$ cells from unrelated-donor marrow grafts: results from BMTCTN 0201. J Clin Oncol (2014) 32(22):2365-72. doi:10.1200/JCO.2013.54.4577 
27. Przepiorka D, Weisdorf D, Martin P, Klingemann HG, Beatty P, Hows J, et al. 1994 consensus conference on acute GVHD grading. Bone Marrow Transplant (1995) 15(6):825-8.

28. Breiman L. Random forests. Mach Learn (2001) 45(1):5-32. doi:10.1023/ A:1017934522171

29. R Core Team. R: A Language and Environment for Statistical Computing. Vienna, Austria: R Foundation for Statistical Computing (2012).

30. Kuhn M, Wing J, Weston S, Williams A, Keefer C, Engelhardt A, et al. Caret: Classification and Regression Training. R Package Version 6.0-64. (2015). Available from: http://CRAN.R-project.org/package $=$ caret

31. Choi SW, Levine JE, Ferrara JL. Pathogenesis and management of graftversus-host disease. Immunol Allergy Clin North Am (2010) 30(1):75-101. doi:10.1016/j.iac.2009.10.001

32. Podgorny PJ, Liu Y, Dharmani-Khan P, Pratt LM, Jamani K, Luider J, et al. Immune cell subset counts associated with graft-versus-host disease. Biol Blood Marrow Transplant (2014) 20(4):450-62. doi:10.1016/j.bbmt. 2014.01.002

33. Vasu S, Geyer S, Bingman A, Auletta JJ, Jaglowski S, Elder P, et al. Granulocyte colony-stimulating factor-mobilized allografts contain activated immune cell subsets associated with risk of acute and chronic graft-versus-host disease. Biol Blood Marrow Transplant (2016) 22(4):658-68. doi:10.1016/j. bbmt.2015.12.015

34. Franzke A. The role of G-CSF in adaptive immunity. Cytokine Growth Factor Rev (2006) 17(4):235-44. doi:10.1016/j.cytogfr.2006.05.002

35. Korbling M, Freireich EJ. Twenty-five years of peripheral blood stem cell transplantation. Blood (2011) 117(24):6411-6. doi:10.1182/blood-2010-12322214

36. Vendramin A, Gimondi S, Bermema A, Longoni P, Rizzitano S, Corradini P, et al. Graft monocytic myeloid-derived suppressor cell content predicts the risk of acute graft-versus-host disease after allogeneic transplantation of granulocyte colony-stimulating factor-mobilized peripheral blood stem cells. Biol Blood Marrow Transplant (2014) 20(12):2049-55. doi:10.1016/ j.bbmt.2014.09.011

37. D’Aveni M, Rossignol J, Coman T, Sivakumaran S, Henderson S, Manzo T, et al. G-CSF mobilizes $\mathrm{CD}^{+} 4^{+}$regulatory monocytes that inhibit graftversus-host disease. Sci Transl Med (2015) 7(281):281-ra42. doi:10.1126/ scitranslmed.3010435

38. Chakraverty R, Sykes M. The role of antigen-presenting cells in triggering graft-versus-host disease and graft-versus-leukemia. Blood (2007) 110(1):9-17. doi:10.1182/blood-2006-12-022038

39. Zhang L, Chu J, Yu J, Wei W. Cellular and molecular mechanisms in graft-versus-host disease. J Leukoc Biol (2016) 99(2):279-87. doi:10.1189/ jlb.4RU0615-254RR

40. Orrú V, Steri M, Sole G, Sidore C, Virdis F, Dei M, et al. Genetic variants regulating immune cell levels in health and disease. Cell (2013) 155(1):242-56. doi:10.1016/j.cell.2013.08.041

41. Brodin P, Jojic V, Gao T, Bhattacharya S, Angel CJ, Furman D, et al. Variation in the human immune system is largely driven by non-heritable influences. Cell (2015) 160(1-2):37-47. doi:10.1016/j.cell.2014.12.020

42. Ottinger H, Beelen D, Scheulen B, Schaefer U, Grosse-Wilde H. Improved immune reconstitution after allotransplantation of peripheral blood stem cells instead of bone marrow. Blood (1996) 88(7):2775-9.

43. Körbling M, Anderlini P. Peripheral blood stem cell versus bone marrow allotransplantation: does the source of hematopoietic stem cells matter? Blood (2001) 98(10):2900-8. doi:10.1182/blood.V98.10.2900

44. Korbling M, Zander A. Stem cell grafts. Hematopoietic Stem Cell Transplantation: A Handbook for Clinicians. 2nd ed. Bethesda, MD (2014). p. 191-8.
45. Zubair AC, Kao G, Daley H, Schott D, Freedman A, Ritz J. CD34 ${ }^{(+)}$CD $38^{(-)}$ and CD34 ${ }^{(+)} \mathrm{HLA}_{-} \mathrm{DR}^{(-)}$cells in BM stem cell grafts correlate with short-term engraftment but have no influence on long-term hematopoietic reconstitution after autologous transplantation. Cytotherapy (2006) 8(4):399-407. doi:10.1080/14653240600847241

46. Mielcarek M, Martin PJ, Heimfeld S, Storb R, Torok-Storb B. CD34 cell dose and chronic graft-versus-host disease after human leukocyte antigen-matched sibling hematopoietic stem cell transplantation. Leuk Lymphoma (2004) 45(1):27-34. doi:10.1080/1042819031000151103

47. Martin PS, Li S, Nikiforow S, Alyea EP, Antin JH, Armand P, et al. Infused total nucleated cell dose is a better predictor of transplant outcomes than CD $34^{+}$ cell number in reduced-intensity mobilized peripheral blood allogeneic hematopoietic cell transplantation. Haematologica (2016) 101(4):499-505. doi:10.3324/haematol.2015.134841

48. Reshef R, Huffman AP, Gao A, Luskin MR, Frey NV, Gill SI, et al. High graft CD8 cell dose predicts improved survival and enables better donor selection in allogeneic stem-cell transplantation with reduced-intensity conditioning. J Clin Oncol (2015) 33(21):2392-8. doi:10.1200/JCO.2014.60.1203

49. Miura Y, Thoburn CJ, Bright EC, Phelps ML, Shin T, Matsui EC, et al. Association of Foxp3 regulatory gene expression with graft-versus-host disease. Blood (2004) 104(7):2187-93. doi:10.1182/blood-2004-03-1040

50. Hess AD. Modulation of graft-versus-host disease: role of regulatory T lymphocytes. Biol Blood Marrow Transplant (2006) 12(1 Suppl 2):13-21. doi:10.1016/j.bbmt.2005.11.002

51. Auletta JJ, Devine SM, Waller EK. Plasmacytoid dendritic cells in allogeneic hematopoietic cell transplantation: benefit or burden? Bone Marrow Transplant (2016) 51(3):333-43. doi:10.1038/bmt.2015.301

52. Swiecki M, Colonna M. The multifaceted biology of plasmacytoid dendritic cells. Nat Rev Immunol (2015) 15(8):471-85. doi:10.1038/nri3865

53. Peric Z, Cahu X, Malard F, Brissot E, Chevallier P, Guillaume T, et al. Peripheral blood plasmacytoid dendritic cells at day 100 can predict outcome after allogeneic stem cell transplantation. Biol Blood Marrow Transplant (2015) 21(8):1431-6. doi:10.1016/j.bbmt.2015.04.003

54. Nishimori H, Maeda Y, Tanimoto M. Chronic graft-versus-host disease: disease biology and novel therapeutic strategies. Acta Med Okayama (2013) 67(1):1-8.

55. Zhou X, Bailey-Bucktrout SL, Jeker LT, Penaranda C, Martinez-Llordella M, Ashby M, et al. Instability of the transcription factor Foxp3 leads to the generation of pathogenic memory T cells in vivo. Nat Immunol (2009) 10(9):1000-7. doi:10.1038/ni.1774

56. Mahadeo KM, Masinsin B, Kapoor N, Shah AJ, Abdel-Azim H, Parkman R. Immunologic resolution of human chronic graft-versus-host disease. Biol Blood Marrow Transplant (2014) 20(10):1508-15. doi:10.1016/j.bbmt.2014.06.030

57. Syme R, Bajwa R, Robertson L, Stewart D, Gluck S. Comparison of CD34 and monocyte-derived dendritic cells from mobilized peripheral blood from cancer patients. Stem Cells (2005) 23(1):74-81. doi:10.1634/stemcells.2004-0070

Conflict of Interest Statement: The authors declare that the research was conducted in the absence of any commercial or financial relationships that could be construed as a potential conflict of interest.

Copyright ( $(2016$ Impola, Larjo, Salmenniemi, Putkonen, Itälä-Remes and Partanen. This is an open-access article distributed under the terms of the Creative Commons Attribution License (CC BY). The use, distribution or reproduction in other forums is permitted, provided the original author(s) or licensor are credited and that the original publication in this journal is cited, in accordance with accepted academic practice. No use, distribution or reproduction is permitted which does not comply with these terms. 